\title{
Conditions for Employee Learning and Innovation - Interweaving Competence Development Activities Provided by a Workplace Development Programme with Everyday Work Activities in SMEs
}

\author{
Agneta Halvarsson Lundkvist ${ }^{1}$ (D) - Maria Gustavsson ${ }^{1,2}$
}

Received: 4 July 2016/Accepted: 3 April 2017 /

Published online: 27 April 2017

(C) The Author(s) 2017. This article is an open access publication

\begin{abstract}
The aim of this article is to investigate how the formal competence development activities provided by the Production Leap, a workplace development programme (WPDP), were interwoven with everyday work activities and to identify the conditions that enabled learning and employee-driven innovation that contributed to production improvement, in small and medium-sized enterprises (SMEs) in Sweden. The study adopts a qualitative case approach and draws on evidence from research conducted in four manufacturing SMEs that participated in this Swedish WPDP. Funded by EU authorities, WPDPs provide competence development activities to SMEs in order to boost their production capabilities and/or promote innovation. The findings reveal that the competence development activities provided by the programme triggered learning in everyday work activities and fostered the development of different approaches to employee-driven innovation in the enterprises. The conclusion is that it is essential to consider that employeedriven innovations may take different forms and involve functions that can support innovative learning that goes beyond minor adjustments to the existing standards of production. Moreover, employee-driven innovation may impose new demands on management leadership skills. The findings provide important guidance for future WPDPs, for vocational education and training or university activities that are customised to SME contexts to promote production capabilities, and for SMEs that aim to strengthen employee-driven innovation.
\end{abstract}

Agneta Halvarsson Lundkvist

agneta.halvarsson.lundqvist@liu.se

1 Department of Behavioural Sciences and Learning (IBL)/Division of Education and Sociology (APS), Linköping University, 58183 Linköping, Sweden

2 Helix Competence Centre, Linköping University, 58183 Linköping, Sweden 
Keywords Workplace learning - Employee-driven innovation - Workplace development programme $\cdot$ Small and medium-sized enterprises

\section{Introduction}

In recent years, a growing number of workplace development programmes (WPDPs), funded by the EU, national governments or regional authorities, have provided competence-building activities to small and medium-sized enterprises (SMEs) to boost production capabilities and/or promote innovation (Alasoini 2009, 2016). In Sweden, one such initiative is the national WPDP, the Production Leap, which was created to increase Swedish SMEs' global competitiveness. More than 200 manufacturing enterprises have participated in the programme's key competence development components, which include university courses in Lean Production and coaching for employees in single enterprises. However, research shows that skills and competence development is a resource-intensive activity, and SMEs find it difficult to assess what activities they need to engage in to build employee competences; therefore, any public investment in SME skills development and competence building should "offer SMEs a way to systematise their training practices" (OECD 2013:13). Previous research provides strong evidence that competence development in SMEs takes on different forms, and its conditions for competence development are different from those in larger enterprises (Matlay 2004). SMEs often find it difficult to upgrade workers' skills and competences because vocational education or training is seldom demand driven or customised for SME contexts. In addition, the ability of regional universities to support innovative processes in SMEs has been questioned (OECD 2013). Consequently, this article argues that competence development efforts in SMEs must be integrated into everyday work activities and be supported by management (Ellström 2010b, 2011; Evans 2015). The strategy for competence development is thus connected to the learning environment within the organisation, which suggests that "learning at work is a matter of design" (Ellström 2011:107). A large number of studies on workplace learning show that a variety of organisational conditions and individual prerequisites intertwine to create learning environments that either support or limit learning and competence development within the workplace (Billett 2001; Ellström 2006; Evans et al. 2006; Felstead et al. 2009; Gustavsson 2009). Competence development efforts in SMEs must therefore be backed up with a supportive learning environment that provides opportunities for employees to engage in work activities in new ways, such as through participation in employee-driven innovations, which can increase output from competence development activities in the form of work practice changes (Evans and Waite 2010).

The aim of this article is to investigate how the formal competence development activities provided by the Production Leap WPDP were interwoven with everyday work activities and to identify the conditions that enabled learning and employeedriven innovation that contributed to production improvements in SMEs. The study draws on evidence from research conducted in four manufacturing SMEs that participated in this Swedish WPDP.

The article is organised into five sections. The following section briefly reviews the theoretical framework, which is based mostly on social and situated perspectives of 
workplace learning and employee-driven innovation. The third section describes case studies of four Swedish manufacturing SMEs and the methodology. The fourth section presents the findings of the conditions that enabled learning that could improve SME production processes. The last section discusses the findings. The analysis indicates that the competence development activities provided by the programme triggered innovation and that different approaches to employee-driven innovations were developed within the enterprises.

\section{Learning and Employee-Driven Innovation}

This study approaches workplace learning by drawing on social and situated perspectives of learning (Lave and Wenger 1991), in which learning is seen as embedded in everyday work and the workplace is considered a crucial site for learning (Billett 2004; Evans et al. 2006; Fuller and Unwin 2004; Gustavsson 2009). Workplace learning is thus conceived as a participatory and relational process in which human capacities are expanded in and through everyday work activities. Workplace learning can take on many forms in a wide variety of situations that can have both formal and informal features (Malcolm et al. 2003). However, there is no clear boundary between formal and informal learning activities, and it is sometimes difficult to separate the two (Malcolm et al. 2003; Marsick et al. 2008; Manuti et al. 2015). Most workplace learning takes place in everyday work activities, but workplaces also engage in externally led competence development activities that are more formal (Billett 2001; Ellström 2006; Evans et al. 2006).

Previous research emphasises the importance of integrating formal competence development activities with daily work activities to achieve the desired competences in the organisation (Ellström 2011; Evans 2015). The successful integration of competence development activities and everyday work activities places strong demands on the internal context of the organisation, that is, on the workplace as an environment not only for production but also for learning and the development of employees and the organisation (Fuller and Unwin 2011). The workplace environment creates rich or poor conditions for learning, some of which arise from the working conditions per se, work tasks, social interactions, strategies for competence development and managerial support (Ellström et al. 2008; Evans et al. 2006; Fuller and Unwin 2004). It is therefore necessary to support and organise rich learning opportunities to be able to move away from well-known work routines and towards new ideas and innovativeness (Ellström 2010a; Gustavsson 2009). If the environment affords rich learning opportunities, learning is more likely to be innovative, whereas adaptive (non-innovative) learning is associated with poorer learning environments (Ellström 2006; Engeström 2001; Fuller and Unwin 2004; Gustavsson 2009).

Studies on employees with low-grade jobs demonstrate that participating in formal workplace competence programmes can trigger employees to change their work practices if the workplace offers an interplay between formal learning activities and everyday work activities, such as coaching from co-workers or focused workplace discussions (Evans and Waite 2010; Waite et al. 2012). However, Evans and Waite (2010) note that the interplay between formal and informal learning activities is complex and that it is dependent on the workplace learning environment and employee agency. The latter, employees' agency, is closely connected to individuals' learning 
dispositions - that is, their personalities and prior learning trajectories (Billett 2004; Evans et al. 2006; Hodkinson et al. 2008), or learning territories, which emphasise individuals' personal learning biographies (Felstead et al. 2009). The workplace learning environment and individuals' learning dispositions influence individuals' ability to take part in learning and employee innovation, and some employees are more likely to engage in innovative learning than others (Gustavsson 2012). Nevertheless, organisations with a poor learning environment will not achieve a full pay-off on their investments in competence development programmes in the long run (Evans and Waite 2010). If the learning environment is sufficient and allows for an interplay between formal learning activities and learning in everyday work activities, external competence development programmes may support the development of a knowledgeable practice (Evans 2015; Waite et al. 2012). Knowledgeable practices are workplaces where employees have the knowledge not only to perform their work but also to change it in a way that is beneficial for both employees and the organisation (Waite et al. 2012).

There is no sense in targeting innovative learning in the workplace without creating the necessary conditions for innovation. In rich learning environments, workplace learning and innovation go hand in hand (Billett 2012; Evans 2015; Høyrup 2012; Price et al. 2012; Saunders et al. 2013). Workers' resources, such as their ideas, creativity, competence and problem-solving abilities, can drive innovations when innovative activities are embedded in employees' everyday work practices (Billett 2012; Ellström 2010a; Evans 2012; Fogelberg Eriksson 2014 Price et al. 2012;). Billett (2012: 94) explains, "both ordinary and innovative practices have to be employee-driven, because it is workers who enact work tasks, confront new challenges and respond to those new tasks". Employee-driven innovation refers to the "generation and implementation of new ideas, products and processes originating from interactions of employees not assigned to this task" (Høyrup et al. 2012:8). Ellström (2010a, b), who uses the term 'practice-based innovation', shows how work practices can form the basis for innovations. Innovations can emerge spontaneously, informally and in an unplanned manner but can also be structured in formal and organised activities (Ellström 2010a). Innovations come about when the prescribed routine work, which is an explicit dimension of the work practice, interplays with the work process as it is performed in practice (Ellström 2010a). Practiced work is not always performed as prescribed, and this may result in new, often tacit, ideas on how to change work practices. To make full-scale changes throughout a workplace, the new knowledge that arises in such a process needs to be made explicit so that a more adaptive form of learning can take place for those who are not familiar with the new work practice (Ellström 2010a).

Thus, employee-driven innovation mainly takes the form of a bottom-up process that needs to be recognised and supported in various organisational and managerial ways (Høyrup 2010). A fully fledged, bottom-up, employee-driven innovation is rare, and ongoing activities of different scales occurring simultaneously would make it difficult to distinguish whether is the process is top-down or bottom-up (Evans 2015). Høyrup (2012) therefore suggests three different orders of employee-driven innovation. The first order is a bottom-up process that is entirely initiated and run by employees; the second is a mixture of bottom-up and top-down approaches, in which employees initiate an innovation process that is supported and coordinated by management; and the third order is employee development that is initiated by management and thus is mainly a top-down process. Third-order employee-driven innovation is further developed by Van Hootegem et al. (2012) into 1) delegation, 2) ideation and 3) 
execution. Delegation refers to the involvement of employees in both the development and implementation of the innovation, and they have a certain degree of autonomy. Ideation refers to employees' contribution of ideas and advice on innovations, which management decides whether to incorporate. Execution is when employees change existing work practices to make room for an innovation suggested by management. Van Hootegem et al. (2012) question whether execution can be considered employee-driven innovation. Similar to Høyrup (2012) and Van Hootegem et al. (2012), Hasu et al. (2015) show that different roles in an organisation are required to develop and sustain user-driven innovation, which is similar to the concept of employee-driven innovation. Hasu et al. (2015) argue that which role(s) - employee, user or management - is currently needed depends on the innovation stage. Employee-driven innovation also shares some similarities with the concept of workplace innovation (sometimes referred to as non-technical, social or organisational innovation), in which bridges between the strategic knowledge of the leadership and the tacit knowledge of frontline employees are built (Gold et al. 2012). Significant statistical evidence reveals modest positive effects on both organisations and individuals in organisations that engage in workplace innovation (Pot 2011; Pot et al. 2012). However, there is some evidence that ungoverned employee participation in innovation decisions could be counterproductive from an organisational perspective (Kesting and Parm Ulhøi 2010).

Employee-driven innovation (and similar concepts), related to employee engagement in innovation processes, is an underexplored area in many organisations (Aasen et al. 2012), and it is seldom included in enterprises' norms (Teglborg et al. 2012; Hansen et al. 2012). The knowledge about employees' contribution to innovation is limited. The role of employees as potential drivers of innovation receives far less attention from researchers than R\&D does, user-driven innovation being an exception (Evans 2012), although evidence suggests that enterprises' innovation capacity depends not only on science-technology innovation but also on employees' innovative competencies (Møller 2010). Furthermore, employee-driven innovation is considered a main driver for competitiveness in the manufacturing sector (Taisch 2014), and innovation and employees' workplace learning are priorities in EU policy (EESC 2011). However, in regard to employee-driven innovation, there is no "best practice" (Aasen et al. 2012); instead, employees' learning and innovation capacity may be a matter of workplace design (Ellström 2011). As is argued in this article, based on workplace learning research, rich learning environments open up possibilities for competence building and everyday innovation, and innovative behaviour can be fostered through the interweaving of formal competence development activities provided by a WPDP with everyday work activities in work practice. The next section gives insight into the WPDP and the enterprises in which the competence development activities provided by the WPDP were interwoven with everyday work activities.

\section{Methods}

\section{Research Settings}

Case studies were carried out in four manufacturing SMEs. The SMEs were geographically located in the same region but manufactured different types of products. All had 
been in business for more than 40 years and had 45-225 employees on site. Enterprises $\mathrm{A}, \mathrm{B}$ and $\mathrm{C}$ were family owned, while enterprise $\mathrm{D}$ was part of a multi-national company based abroad. More facts on the SMEs are presented in Table 1.

The Production Leap WPDP was initiated in 2006 in Sweden. At the enterprises studied, top-level managers took the initiative to join the WPDP. Enterprise A joined the programme in 2009, and the three other enterprises joined in 2012. The programme was partly funded by three major public financiers (Vinnova, the Swedish Agency for Economical and Regional Growth, and the Knowledge Foundation) and partly by fees paid by participating companies.

The programme's aim was to strengthen Swedish manufacturing enterprises' competitiveness in a global market by offering subsidised university education and on-site coaching within SMEs, and it aimed to increase the productivity and innovation capacities of participating enterprises. It was required that a minimum of two managers or Lean coordinators from each enterprise attend a university course (7.5 ECT credits). The on-site coaching methods were based on Lean principles such as standardised processes, levelled production, Just-In-Time (JIT) practices, visual inspection, continuous improvement (Womack et al. 1991; Womack and Jones 1996), and each enterprise's context-specific needs to meet future challenges or improve their performance. All participating enterprises were coached for a minimum of 18 months, fortnightly for the first year and every four weeks for the last six months. These occasions comprised one-day visits from one or two of the coaches assigned to the enterprise. Three of the studied enterprises (B, C, D) had recently completed the programme, and enterprise A had done so three years prior to the study. It is worth noting that a sociotechnical tradition strongly influences the interpretation of Lean in the Nordic countries, which increases union support for Lean implementation, workers' responsibility and authority, and workers' opportunities for participation and learning (Eklund et al. 2015).

\section{Data Collection}

The study adopted a qualitative case approach consisting of 17 individual semistructured interviews. Sixteen of the interviews were conducted with enterprise employees (all men) ranging from top management levels to operators (Table 2).

Table 1 Facts on participating SMEs

\begin{tabular}{|c|c|c|c|c|}
\hline & Enterprise A & Enterprise B & Enterprise C & Enterprise D \\
\hline Founded in & 1907 & 1967 & 1948 & 1940 (Site) \\
\hline Ownership & $\begin{array}{l}\text { Family-owned company } \\
\text { group (1600 employees) }\end{array}$ & Family owned & Family owned & $\begin{array}{l}\text { Multi-national } \\
\text { company }(25,000 \\
\text { employees })\end{array}$ \\
\hline Products & $\begin{array}{l}\text { Metal packaging } \\
\text { units }\end{array}$ & $\begin{array}{l}\text { Turnkey solutions } \\
\text { for control and } \\
\text { power } \\
\text { automation }\end{array}$ & $\begin{array}{l}\text { Suppliers of advanced } \\
\text { cutting machinery } \\
\text { for the heavy } \\
\text { vehicle industry }\end{array}$ & $\begin{array}{l}\text { Packaging and paper } \\
\text { solutions }\end{array}$ \\
\hline $\begin{array}{l}\text { Number of } \\
\text { employees }\end{array}$ & 98 & 45 & 225 & 133 \\
\hline
\end{tabular}

*The production leader/Lean coordinator had been an operator during most of the programme 
Table 2 Participating respondents from the enterprises

\begin{tabular}{llll}
\hline Enterprise A & Enterprise B & Enterprise C & Enterprise D \\
\hline $\begin{array}{lll}\text { 1. Operator } \\
\text { 2. Operator }\end{array}$ & $\begin{array}{l}\text { 1. Operator } \\
\text { 2. Designer/Lean } \\
\text { coordinator }\end{array}$ & $\begin{array}{l}\text { 1. Operator } \\
\text { 2. Production manager/Lean } \\
\text { coordinator }\end{array}$ & $\begin{array}{l}\text { 1. Sales manager } \\
\text { 2. Production leader/Lean } \\
\text { coordinator* }\end{array}$ \\
$\begin{array}{l}\text { 3. Production leader } \\
\text { 4. Production manager }\end{array}$ & $\begin{array}{l}\text { 3. Production manager } \\
\text { 4. CEO }\end{array}$ & $\begin{array}{l}\text { 3. Production manager } \\
\text { 4. CEO }\end{array}$ & $\begin{array}{l}\text { 3. Production manager } \\
\text { 4. CEO }\end{array}$ \\
\hline
\end{tabular}

The operators in enterprises A, C and D had similar tasks, operating machinery, while the operators in enterprise B assembled parts. In comparison, the operators in enterprise B, who assembled parts, worked more autonomously. The production leaders in enterprises A and D managed production lines, while the production managers in all enterprises monitored the operative work in part or all of the plant. The CEOs were all up to date with the on-going Lean implementation, although they were not involved in the operative work on a daily basis. A CEO or production manager had appointed the Lean coordinators. The Lean coordinators had slightly different tasks and responsibilities. However, they all communicated with management regarding the operative Lean implementation and aspired to function as internal Lean coaches for the workers (albeit, according to them, with mixed success). The Lean coordinator in enterprise B worked as a design engineer, while the two Lean coordinators in enterprises $\mathrm{C}$ and $\mathrm{D}$ worked in production. In enterprise A, production engineers monitored the Lean implementation.

The researchers conducted the seventeenth interview with the enterprises' assigned coach to capture his view of the activities provided in the programme. This coach also assisted the researchers in selecting the enterprises. The criteria set by the researchers was that the enterprises had actively taken part in WPDP activities but were no longer being coached by the programme, had been coached by the same coach, had different types of products and production systems, and (for practical reasons) were located in the same region. The coach perceived that the prior coaching was successful in the selected enterprises, although each experienced its specific problems and bumps along the way. However, no enterprise stood out as having an exceptionally good learning environment or other favourable conditions in comparison with other enterprises in the WPDP. The researchers contacted four enterprises he recommended and instructed the contact person (the CEO) to select a minimum of four informants from different levels of the enterprise. All interviews were conducted on-site at the enterprises. An interview guide was used, which included seven themes: 1) background data, 2) competence-building activities provided by the WPDP 3) contextual conditions, 4) learning opportunities, 5) measurement and follow-ups, 6) improvements and effects, and 7) the future - plans and expectations. The interviews lasted for 40-70 min and were recorded and transcribed verbatim. In connection with the interviews, the researchers were given a guided tour of each enterprise, which allowed them valuable opportunities to talk informally with managers and operators and aided their understanding of production processes, the formal competence-building activities that had taken place, and their impact or lack thereof on daily activities. 


\section{Data Analysis}

The data analysis was based on the interview transcripts. First, the researchers read all the transcripts to gain a broad understanding of the material. In the next step, they conducted a qualitative content analysis, which resulted in the categorisation of four main learning conditions: competence development activities and support by the coach provided by the WPDP, organisational conditions, employees' commitment and engagement, and the development of an internal support structure. Then, the researchers performed a comparison of the enterprises, focusing how the competence development activities provided by the WPDP were interwoven with everyday work activities and the conditions that enabled learning and employee-driven innovation. More specifically, in the last analysis step, the researchers focused on support structures that were built into the everyday work activities to promote employee learning and innovation after the enterprise had left the programme.

\section{Findings}

This section presents the competence development activities provided by the WPDP and the conditions that supported learning, which could in turn potentially improve the production processes within the four enterprises.

\section{Competence Development Activities and Support Provided by the Programme}

Initially, the WPDP had a formal learning support structure, and the coach used a wide range of standardised activities to improve the enterprises' capabilities and workers' commitment to learning at work. As a first learning activity, a Lean Production (Lean) steering group was formed in each enterprise. The steering group included top management, Lean coordinators, production managers, union representatives, and other key personnel. The Lean steering group was meant to be the hub and driving force for the implementation of Lean in the enterprises. In particular, the steering group was tasked with creating a dialogue with the programme's coach. The steering group and the coach discussed challenges and ambitions of changing the production processes, formed local Lean principle guidelines, made a plan of action, decided on work methods, and set key goals for production improvements. To support the steering group's learning, the coach organised competence-building activities during the group's one-day visits. The first important step was for each steering group to define and communicate the enterprises' guiding principles and production system. The group often did so in an extended Lean steering group format and invited a few union officials and operators to participate.

The assigned coach described the Lean steering group in enterprise A as 'a homogenous group that spent a decent amount of time on the Lean implementation work'. The coach described enterprise B's Lean steering group as being very active. This enterprise had also sent five individuals from the Lean steering group to the university Lean course offered by the WPDP. A few members of the steering group in enterprise $\mathrm{C}$ had some difficulty with unengaged members, and the coach described the steering group in enterprise D as 'young and confused'. The importance of the Lean steering group is shown in the following quote, where a production manager in enterprise $\mathrm{C}$ states his frustration with his management colleagues who would not engage in the Lean steering 
group's activities, thus leaving the Lean implementation work to be managed by the production units:

The management is competent enough, but I am afraid that some of them lack engagement ... they think that this [the Lean implementation work] does not really apply to them. I felt right from the beginning that they sort of thought that their jobs were so important that they didn't need to attend these meetings, so they would disappear in a middle of a meeting to take phone calls ... things like that ... so I think that we could actually get more out of the Lean steering group. There were [four people] who were really the front men who pushed this forward. (Production manager Enterprise C)

Operators were also involved in the competence activities in all of the enterprises. Most of the employees attended an introduction day, which covered the theory behind the Lean concept and included a game that presented the principles of Lean Production. The most common working methods that the coach taught or demonstrated were improvement groups, value flow analysis, housekeeping, standardised work and visualisation, all commonly described tools in Lean Production literature.

All enterprises were engaged in some development work to develop continuous improvement work, and it was an important task for the assigned enterprise coach to support this work. The aim was to develop a system in each enterprise that allowed improvement potential to be detected through the identification and documentation of problems or deviation from set standards. Then, the actual improvement work was carried out individually by workers, engineers or management or in improvement groups. The enterprises organised this work with the support of the assigned coach.

The formal training and actual development work differed according to each enterprise's context. In all enterprises, managers and production personnel, including operators, played the Lean game, attended the university course (some managers and Lean coordinators), were trained in housekeeping and developed their continuous improvement work. Table 3 sums up the formal training and the areas that the enterprises developed with support from the coach.

In enterprise $\mathrm{A}$, production engineers monitored the Lean implementation work. These engineers attended the university course offered by the programme. Enterprise B, which was smaller than enterprise A, developed a Lean steering group that kept track of daily deviations and improvement work. Enterprise $\mathrm{C}$ developed a system for introducing new work practices and had a person responsible for that in different areas, such as housekeeping and value stream mapping. Enterprise D, however, spent little time on actual development areas. One reason for that was, as the assigned coach said, "It was difficult for them to do things until they discovered why they should do them".

\section{Organisational Conditions}

As with the activities and external support provided by the programme, described above, some organisational conditions were similar across enterprises, while others were not. The conditions that the interviewees mentioned as the most indispensable for success in Lean implementation were supportive management, training, and time for 
Table 3 Formal training and implemented Lean tools

\begin{tabular}{|c|c|c|}
\hline Enterprise & Formal training & Development areas \\
\hline A & $\begin{array}{l}\text { Lean game, extra Lean theory for all, university } \\
\text { course, housekeeping, SMED (reduce set-up } \\
\text { time), improvement work }\end{array}$ & $\begin{array}{l}\text { Housekeeping, SMED, structured individual } \\
\text { improvement work, follow-ups, } \\
\text { visualisation }\end{array}$ \\
\hline B & $\begin{array}{l}\text { Lean game, university course, housekeeping, } \\
\text { workshop for Lean steering group, daily } \\
\text { steering, improvement work }\end{array}$ & $\begin{array}{l}\text { Improvement work, improvement methods, } \\
\text { improvement groups, daily steering }\end{array}$ \\
\hline $\mathrm{C}$ & $\begin{array}{l}\text { Lean game and extra Lean theory for all, } \\
\text { university course, housekeeping, training for } \\
\text { Lean steering group, daily steering, } \\
\text { improvement work, other Lean tools }\end{array}$ & $\begin{array}{l}\text { Housekeeping, SMED, improvement work, } \\
\text { improvement groups, daily steering, root } \\
\text { problem analysis, standardisation, value } \\
\text { flow analysis, }\end{array}$ \\
\hline $\mathrm{D}$ & $\begin{array}{l}\text { Lean game, university course, housekeeping, } \\
\text { training for Lean steering group, daily } \\
\text { steering, improvement work }\end{array}$ & $\begin{array}{l}\text { Housekeeping, improvement groups, daily } \\
\text { steering }\end{array}$ \\
\hline
\end{tabular}

continuous improvement work. The Lean coordinator in enterprise D expressed why support from management was important:

You can try to implement Lean as much as you want, but without management support, implementation is slow. It is then uncommon to take more than a few hesitant steps at the beginning, before you notice that the management support you need and want isn't there and you simply don't have the energy to fight the uphill battle. (Lean coordinator Enterprise D)

The assigned coach who had also worked with the other enterprises agreed on the importance of a supportive management team.

In nine cases out of ten, the major concern is management support. This support has a huge impact. The CEO's participation shows the importance of the idea to the others. (Assigned coach)

The enterprises differed in terms of how the interviewees perceived support from management. Interviewees in all enterprises observed a driving engagement, although not always from top management. In enterprises $\mathrm{A}$ and $\mathrm{D}$, the assigned coach questioned top management's level of commitment. Management's ambivalence seemed to be mitigated by the assigned production engineers who were part of the management group in enterprise $\mathrm{A}$. In enterprise $\mathrm{D}$, the $\mathrm{CEO}$ was committed to implementing Lean but was sometimes reluctant to take the advice given by the assigned coach.

I have had to work a lot with the CEO [D], who thought that he knew how things should be done because he had implemented Lean in another company. (Assigned coach)

In enterprises $\mathrm{B}$ and $\mathrm{C}$, the interviewees did not question management's commitment and engagement. 
The amount of time allocated to participation in training and development work varied between the enterprises. As an example, enterprise $\mathrm{C}$ was able to proceed quickly with the formal training due to a temporary shortage of incoming orders. This extra time could be used in the actual development work supported by the programme's coach. One example of extra time spent on development work in Enterprise $\mathrm{C}$ was when the steering group planned and described the enterprise's guiding principles and production system. In three of the enterprises, this description was later printed in pamphlets that were distributed to workers and customers.

We tried to work a lot so that we could produce this [the pamphlet] ... so that we didn't copy somebody else's, but it rather shows that this is what we believe in and are guided by. This was something that we put a lot of time into at the beginning. (Production manager 2 Enterprise C)

The time that the enterprises spent on continuous improvement work also varied. Enterprise A allocated time only when production allowed for it. Enterprise B allocated one hour per week per worker for improvement work. The interviewees in enterprise $\mathrm{C}$ felt that there was time for continuous improvement work most weeks, although no time was allocated to it. Enterprise D allocated the least amount of time for actual improvement work due to a lack of employees' willingness to participate, a recent downsizing, and difficulty in getting different shifts to work together.

In addition, there were other organisational conditions worth noting. As mentioned, enterprises A, B and C were family owned, while enterprise D was part of a multinational company based abroad. This multi-national company had an international quality team that travelled around Europe to assist in implementing different Lean tools. The interviewees in enterprise D said that this had not worked out in the past. It should also be noted that enterprises $\mathrm{A}$ and $\mathrm{D}$ were process oriented (individual work), while enterprises $\mathrm{B}$ and $\mathrm{C}$ had more of a team base with groups of workers. To some extent, this difference could account for the differences in Lean tools that could be used.

\section{Employee's Commitment and Engagement}

In all enterprises, operators were expected to participate in the internal training. A similarity was that the operators' learning was connected to improvements in production processes, and they were trained on the shop floor as they worked to develop different areas. In enterprise A, the improvement work was individual. The operators were encouraged to take responsibility and suggest improvements that could be made on their line, which would subsequently be approved by the production manager. However, the managers stated that it was difficult for some operators to write down their suggested proposals. If the proposal was not approved, the production leader informed the operator.

The improvement suggestions are now written individually, but you could write them as a group ... the most important thing is that you do the needed improvements. (Production leader Enterprise A) 
Yes, you can leave suggestions, if I see an improvement that can be made on our line, we have three or four lines that are almost identical, so if there is an improvement that can be made on our line, it can often be made on the other lines too. (Operator Enterprise A)

In contrast to enterprise $\mathrm{A}$, enterprises $\mathrm{B}, \mathrm{C}$ and $\mathrm{D}$ formed pilot improvement groups and selected a few operators who worked in a specific section or at a particular machine to participate. Then, they used the pilot as an example to learn from other improvement groups that were set up gradually. As mentioned above, the goal was to achieve continuous improvements through operators continuously solving problems and developing new work procedures while working. Enterprise D also implemented a parallel Lean programme, a three-day course that was given by the multi-national company of which the enterprise was a part. These two programmes differed from one another, as the Swedish WPDP's main point was to create a bottom-up commitment to improve production, while the international programme had a top-down approach, as perceived by the interviewees.

The managers from all four enterprises found it difficult to get all employees to carry out the improvement work. The operators' commitment was important, but in some cases, the managers admitted that it was difficult to obtain. Additionally, the managers had varying opinions about whether to work with employees who were already engaged first or to try to engage unengaged employees simultaneously. All managers realised that changing the production would take time as the operators had to learn new ways of working.

The implementation of Lean requires patience and formal training; that is, if people haven't got the training, then they don't understand why they should do it. That is priority number one /.../ The better training you have, I think, the quicker you can move forward, but you have to respect that it takes time. (Production manager Enterprise A)

Our operators became a bit more independent, but this [the Lean implementation] has proven to be a long process. (Production manager 2 Enterprise C)

And here we keep training, and it takes time, but we did it on the printing machine, and we felt quite confident, and then we said, 'Let's do it so that we will train the operators as we go'. (Production manager Enterprise D)

The operators also expressed difficulty in adapting their thinking to the new methods of working. At first, they were suspicious of the programme, and it was frustrating for some of them. They were more or less forced to learn the new work methods. As they worked with them more and more, they gradually changed their attitudes and started to understand how and why they should use the new methods. Furthermore, some of them became positive and took a more active role in continuous improvement work.

Well, of course, at the beginning, everyone was sceptical, as I said before ... but now everyone is positive, I think. Is everyone positive? Yes, I think so, there is a difference in our production. (Operator 2 Enterprise A) 
It is a new way of working. That is why there is a bit of resistance, but as I said, this would have taken three minutes, but what the heck, half an hour if I am to do it this way [a lot of paperwork for very small changes]. It is all about the mind-set. It is like they [the management] say, in the beginning, we won't be producing any amazing results; we will just be trying to implement a new way of working. (Operator Enterprise B)

In all enterprises, the operators had short, daily meetings with the production managers on the production floor or in an adjacent room. In these meetings, the operators had opportunities to discuss everyday improvements concerning the products, their quality and customers' requests but also production problems. A reflection from a manager in enterprise $\mathrm{D}$ revealed that he too learned that it was important to listen to the operators' opinions and suggestions for improvements.

It leads to participation; it leads to an openness in the team that we are allowed to express ideas and think in another way /.../ Then, you also have to be aware that if you need help and support, you shouldn't be afraid to ask for it. (Marketing manager Enterprise D)

The operators' participation in continuous improvement work and management's encouragement of operators to express their ideas were key factors that affected the operators' learning and consequently their ability to develop new work practices.

\section{Development of an Internal Support Structure}

Both managers and operators perceived that their way of working had changed in ways that improved production, but the enterprises differed in this regard. Whereas management in enterprises A, B and C had plans for how to continue the 'Lean journey' after leaving the programme, management in enterprise $\mathrm{D}$ expressed no immediate plans for continued competence development. However, to develop production, management in enterprise D wanted to try to combine the new knowledge gained through the WPDP with the new knowledge from the Lean Production programme that was provided by the enterprise's international owners.

Enterprises A, B and C kept integrating improvements into the production process. However, these enterprises had different solutions for forming the internal support structure for learning and innovation. Enterprise A created a production engineer department and employed two production engineers who were to back up improvements in production by supporting the operators in solving daily problems. The assigned coach stated that these engineers were very important for the operators' capability to sustain continuous improvement work.

Enterprise B used an employee-driven approach in that the operators were given more responsibilities to solve problems and improve the production process so that the manager's time could be freed up to provide more strategic and coaching leadership than before. The enterprise therefore needed to train managers in coaching leadership in order to continue to train and upgrade the operators' skills. In addition, the active Lean steering group, which was compared to a strengthened management group, gave the 
operators strong support to undertake actions on their own in order to continuously improve production.

Enterprise $\mathrm{C}$ kept the Lean coordinators and developed an internal support structure based on these coordinators, who continued to support the operators in a way that was similar to the support given by the WPDP coach during the programme. The coordinators were responsible for the improvements and helped the operators adapt to the new way of working.

\section{Discussion}

This paper has provided insight into the ways the formal competence development activities and support provided by the Production Leap WPDP were interwoven with everyday work activities within the enterprises, and it has identified the conditions that enabled learning and employee-driven innovation that contributed to production improvements. The findings show that the formal training provided by the WPDP was in many ways similar in the four enterprises, but the development areas, particularly the structured improvement work, differed. This work was performed by either individuals or groups, and it was supported by expertise differently in each enterprise. Therefore, the improvement work was adapted to the enterprises' needs, and the competence development activities were integrated differently into the local workplace context as an individual or collective activity in everyday work.

Overall, the competence development activities provided by the WPDP seemed essential to trigger an innovative learning process and to use the learning potential in work (Ellström 2010a; Engeström 2001; Fuller and Unwin 2004; Gustavsson 2007). The external triggers were important driving forces for learning, but they cannot per se generate innovation unless they are integrated and actively used in core processes (Billett 2012; Ellström 2010a; Evans 2012; Fogelberg Eriksson 2014; Price et al. 2012). Therefore, it appeared important for enterprises to organise so that the competence development activities provided by the WPDP became a part of everyday work; that is, the enterprises interweaved the competence development activities and the everyday work activities to create conditions for employee-driven innovation. The findings show that the WPDP competence development activities and support from the coach were affected by other conditions in the enterprises, such as management support and the amount of allocated time for formal training. They also show that the development work formed different learning environments, which were adapted to the learning needs of each enterprise. In enterprises A, B and C, the external support from the WPDP combined with the organisational conditions contributed to a more enabling learning environment than in enterprise D. In enterprises A, B and C, the interviewees suggested that the coherent and engaged Lean steering groups, allocated time and support from management, were the most important conditions for the operators to carry out improvements while they were working on the shop floor. Thus, the competence development activities and support provided to operators seemed to have a better impact if the learning environment was enabling inside the enterprises. This finding is in line with many other studies of workplace learning (Ellström et al. 2008; Evans et al. 2006; Fuller and Unwin 2004; Gustavsson 2009). 
Notably, the interviewees suggested that a necessary condition in the enterprises, in conjunction with the WPDP, was to gain widespread participation among the operators for collaborative learning. In the beginning, the operators were generally reluctant or unwilling to learn. This is not unusual; other studies have shown that workers' initial suspicion of workplace learning is hard to overcome, especially in SMEs (Brown et al. 2004). This line of argumentation is strengthened by the fact that when the operators were forced to 'jump on the Lean train' and began to suggest or make improvements themselves, the development work progressed more smoothly. The model of learning used in the programme was to link the competence development activities to the operators' handling of everyday production problems encountered in the enterprises. Gradually, this created an enabling learning environment that stimulated innovative learning in the context of continuous improvement work. Earlier research shows that individuals' disposition for learning may influence their recognition of new learning opportunities, which in turn may have an impact on their attitudes towards and actions undertaken for learning (Billett 2001; Evans et al. 2006). In keeping with Evans et al.'s (2006) argument, positive attitudes among the operators and new knowledge created an upward spiral that facilitated more learning and more learning opportunities in work in enterprises A, B and C. The improvements the operators undertook, in turn, had an impact on organisational conditions.

However, the main goal of the WPDP was for the enterprises to create environments that supported innovative learning in order to improve production. If the support provided to both management and operators by the WPDP was integrated into everyday work, a system for continuous improvement work that was connected to learning and innovation was built. However, this was achieved only if the support provided to both management and operators by the WPDP was integrated into everyday work activities, if the other conditions that made up the learning environment were supportive enough, and if the employees' engagement in production improvements was high. This evidence suggests that a more knowledgeable practice, promoting employeedriven innovation (Evans and Waite 2010; Waite et al. 2012), began to evolve gradually through the WPDP. As the findings indicate, enterprises A, B and C developed different approaches to employee-driven innovation, which were supposed to continue to involve the operators in the development of production when the external Lean coach left the enterprises. The analysis revealed that the following approaches to employeedriven innovation were developed:

- Lean coordinator approach

- Engineer approach

- Operator approach

All three approaches involved employees' generation and implementation of ideas and actions (Høyrup 2012) -that is, innovation that goes beyond minor adjustments in the existing standards of production. Compared with a fully operator-driven approach, a Lean coordinator approach and an engineer approach featured more joint learning between operators and Lean coordinators or engineers in the implementation of ideas and actions. Enterprise $\mathrm{C}$ adopted a Lean coordinator approach, embracing the idea of having support in the form of a Lean coordinator - an idea that came to life during the participation in the WPDP. This Lean coordinator kept to the pattern that had been 
developed during the programme and adopted a similar way of working with improvements by supporting the operators' learning of new working methods. This Lean coordinator approach shared similarities with what Høyrup (2012) defines as a second-order employee-driven innovation. The operators drove innovation with support from the Lean coordinator, who was the main communicator with top management. The Lean coordinator helped bridge the ideas and knowledge from the frontline operators to management. Management retained the right to approve or disapprove of the operators suggested changes in the production. Therefore, this approach also appeared to have elements of ideation (Hootegem et al. 2012).

Enterprise A adopted an engineer approach, building up a production engineer department and employing two production engineers. Similar to the Lean coordinator approach, the engineer approach appeared to border on second-order employee-driven innovation (Høyrup 2012). The engineers' function was to support the operators in solving daily problems; thus, operators drove the problem-solving, and the engineers, with their expert knowledge, supported the operators in their problem-solving to improve production. As Ellström (2010a) and Evans (2012) note, problem-solving can drive innovation if innovative activities are embedded in everyday work activities. The operators suggested new ways to improve production, and when management approved the changes, the operators were individually or collectively allowed to implement the improvements. It was still the operators who drove innovation, but since the engineers were part of the management team, they were constantly communicating with management, which at times resulted in combined bottom-up/top-down innovations.

Enterprise B developed an operator-driven approach, which has similarities to Høyrup's (2012) first-order employee-driven innovations. The findings from enterprise $\mathrm{B}$ indicate that the operators were given more and more responsibilities for production improvements, until they were capable of running their own continuous improvement activities. The operators drove innovation and supported one another in changing the work practice, and they communicated directly with top management. The operators were given full responsibility for the improvements, and as they developed new knowledge, innovative behaviour was fostered in the enterprise. Consequently, the managers realised that they needed to devote more time to strategic leadership than before, and therefore, a need to train the managers in coaching leadership emerged. The findings thus indicate that embedding innovative activities, such as continuous improvements, into everyday work may lead to other development needs related to managers' exercise of leadership in order to foster innovative behaviour among employees.

\section{Conclusion}

The findings in this paper, despite deriving from a small number of interviews in each enterprise, give important guidance for future WPDPs, for vocational training or university activities customised for SME contexts to promote production capabilities, and for SMEs that aim to strengthen employee-driven innovation. Based on the empirical findings of this study, the first conclusion is that competence development activities and support provided by the WPDP were important triggers for innovative learning, and if combined with an enabling learning environment in the enterprises, including management's leadership skills in fostering employee-driven innovation, the 
activities in the WPDP became driving forces for employee-driven innovation. The approaches to employee-driven innovations - the Lean coordinator, engineer or operator approaches - developed in the enterprises indicate that employee-driven innovations may take different forms and involve functions that have the capacity to support workers in innovation processes that go beyond minor adjustments to the existing standards of production. In addition, it appeared that the everyday work activities performed by the workers and their communication with supervisors and management continually negotiated the programme's aim - in this case, strengthening Swedish manufacturing enterprises' competitiveness.

The second conclusion is that WPDPs or other publicly funded programmes that aim to promote innovation capacity in participating enterprises (as well as other organisations) need to ensure that their provided competence development activities are interwoven with the participating organisations' everyday work activities. As the findings indicate, a publicly financed WPDP's aim can be realised only through specific outcomes in the participating organisations. In this case, the anticipated outcomes were to build the innovation capacity needed to strengthen production capabilities in order to achieve competitiveness in a global market.

Acknowledgements This research project PEXiSME (Vinnova 2013-02430, Production Excellence in Small and Medium-Sized Enterprises) - was funded by the Swedish Agency for Innovation Systems (VINNOVA). The project involved eight manufacturing enterprises, but the findings in this paper are based on studies carried out in four of the participating enterprises, to whom we owe much gratitude.

Open Access This article is distributed under the terms of the Creative Commons Attribution 4.0 International License (http://creativecommons.org/licenses/by/4.0/), which permits unrestricted use, distribution, and reproduction in any medium, provided you give appropriate credit to the original author(s) and the source, provide a link to the Creative Commons license, and indicate if changes were made.

\section{References}

Aasen, T. M., Amundsen, O., Gressgård, L. J., \& Hansen, K. (2012). Employee-driven innovation in practice: Promoting learning and collaborative innovation by tapping into diverse knowledge sources. Lifelong Learning in Europe, 4, 1-10.

Alasoini, T. (2009). Strategies to promote workplace innovation: A comparative analysis of nine national and regional approaches. Economic and Industrial Democracy, 30(4), 614-642.

Alasoini, T. (2016). Workplace Development Programmes as Institutional Entrepreneurs-Why They Produce Change and Why They Do Not. (PhD thesis). Department of Industrial Engineering and Management, Aalto University.

Billett, S. (2001). Learning through work: Workplace affordances and individual engagement. Journal of Workplace Learning, 13(5), 209-214.

Billett, S. (2004). Learning through work: Workplace participatory practices. In H. Rainbow, A. Fuller, \& A. Munroe (Eds.), Workplace learning in context (pp. 109-125). London: Routledge Taylor and Francis Group.

Billett, S. (2012). Explaining innovation at work: A socio-personal account. In S. Høyrup, M. BonnafousBoucher, C. Hasse, M. Lotz, \& K. Møller (Eds.), Employee-driven innovation (pp. 92-107). Hampshire: Palgrave Macmillan.

Brown, A., Rhodes, E., \& Carter, R. (2004). Supporting learning in advanced supply systems in the automotive and aerospace industries. In H. Rainbow, A. Fuller, \& A. Munroe (Eds.), Workplace learning in context (pp. 166-182). London: Routledge Taylor and Francis Group.

EESC (2011). Opinion of the European economic and social committee on innovative workplaces as a source of productivity and quality jobs. Available at www.Eesc.Europa.Eu/resources/docs/ces543-2011_ac_en. Doc (accessed 15th April, 2016). 
Eklund, J., Halvarsson Lundkvist, A. \& Lindskog, P. (2015). Lean implementation, work environment and sustainability. Sustainable Development in Organizations: Studies on Innovative Practices.(pp. 29-41) Cheltenham: Edward Elgar.

Ellström, P.-E. (2006). Two logics of learning. In E. Antonacopoulou, P. Jarvis, V. Andersen, B. Elkjaer, \& S. Høyrup (Eds.), Learning, working and living. Mapping the terrain of working life learning. Hampshire: Palgrave Macmillan.

Ellström, P.-E. (2010a). Practice-based innovation: A learning perspective. Journal of Workplace Learning, 22(1/2), 27-40.

Ellström, P.E. (2010b). Organizational learning. I P. Peterson, E. Baker \& B. McGaw (Eds.), International encyclopaedia of education (47-52). Elsevier. Ellström, P-E. (2011). Informal learning at work: Conditions, processes and logics. In M. Malloch, L. cairns, K. Evans and B.N. O'Connor (Eds.). The SAGE handbook of workplace learning (pp 105-119).

Ellström, P. E. (2011). Informal learning at work: Conditions, processes and logics. The SAGE handbook of workplace learning, 105-119.

Ellström, E., Ekholm, B., \& Ellström, P.-E. (2008). Two types of learning environments. Enabling and constraining a study of care work. Journal of Workplace Learning, 20(2), 84-97.

Engeström, Y. (2001). Expansive learning at work: Toward an activity theoretical reconceptualization. Journal of Education and Work, 14(1), 133-156.

Eriksson, F. (2014). A gender perspective as trigger and facilitator of innovation. International Journal of Gender and Entrepreneurship, 6(2), 163-180.

Evans, K. (2012). Employee-driven innovation and workplace learning: Exploring present realities, future possibilities and enduring challenges. LLinE, Lifelong Learning in Europe, 4/2012.

Evans, K. (2015). Developing knowledgeable practices at work. In M. Elg, P.-E. Ellström, M. Klofsten, \& M. Tillmar (Eds.), Sustainable development in organizations - Studies on innovative practices (pp. 109-126). Cheltenham: Edward Elgar.

Evans, K., \& Waite, E. (2010). Stimulating the innovation potential of 'routine' workers through workplace learning. Transfer, 16(2), 243-258.

Evans, K., Hodkinson, P., Rainbird, H., \& Unwin, L. (2006). Improving workplace learning. London: Routledge Taylor and Francis Group.

Felstead, A., Fuller, A., Jewson, N., \& Unwin, L. (2009). Improving working as learning. London: Routledge.

Fuller, A., \& Unwin, L. (2004). Expansive learning environments: Integrating organizational and personal development. In H. Rainbird, A. Fuller, \& A. Munro (Eds.), Workplace learning in context. London: Routledge Taylor and Francis Group.

Fuller, A. \& Unwin, L. (2011). Workplace learning and the organization. In M. Malloch, L. cairns, K. Evans and B.N. O'Connor (Eds.). The SAGE handbook of workplace learning (46-59).

Gold, M., Exton, O., Dill, P. \& Exton, R. (2012). Closing the gap between evidence-based and common practice - Workplace innovation and public policy in Europe. LLinE, Lifelong Learning in Europe, 4. http:/www.elmmagazine.eu/articles/closing-the-gap-between-evidence-based-and-common-practiceworkplace-innovation-and-public-policy-in-europe/. Accessed 9 April 2017.

Gustavsson, M. (2007). Potentials for learning in industrial work. Journal of Workplace Learning, 19(7), 453463.

Gustavsson, M. (2009). Facilitating expansive learning in a public sector organization. Studies in Continuing Education, 31(3), 245-259.

Gustavsson, M. (2012). Learning and propensity for changing the job situation during downsizing. Journal of Workplace Learning, 24(7/8), 497-508.

Hansen, K., Gressgård, L., Amundsen, O. \& Aasen, M. (2012). Employee-driven innovation in practice Promoting learning and collaborative innovation by tapping into diverse knowledge sources. LLinE, Lifelong Learning in Europe, 4. http://www.elmmagazine.eu/articles/employee-driven-innovation-inpractice-promoting-learning-and-collaborative-innovation-by-tapping-into-diverse-knowledge-sources/. Accessed 9 April 2017.

Hasu, M., Saari, E., Honkaniemi, L., Tuominen, T., Lehtonen, M., Kallio, K., \& Toivonen, M. (2015). In M. Elg, P.-E. Ellström, M. Klofsten, \& M. Tillmar (Eds.), Sustainable development in organizations - Studies on innovative practices (127-150). Cheltenham: Edward Elgar.

Hodkinson, P., Biesta, G., \& James, D. (2008). Understanding learning culturally: Overcoming the dualism between social and individual views of learning. Vocations and Learning, 1(1), 27-47.

Høyrup, S. (2010). Employee-driven innovation and workplace learning: Basic concepts, approaches and themes. Transfer, 16(2), 143-154. 
Høyrup, S. (2012). Employee-driven innovation: A new phenomenon, concept and mode of innovation. In S. Høyrup, M. Bonnafous-Boucher, C. Hasse, M. Lotz, \& K. Møller (Eds.), Employee-driven innovation (pp. 3-33). Hampshire: Palgrave Macmillan.

Høyrup, S., Bonnafous-Boucher, M., Hasse, C., Lotz, M., \& Møller, K. (2012). Employee-driven innovation: A new approach. Hampshire: Palgrave Macmillan.

Kesting, P., \& Parm Ulhøi, J. (2010). Employee-driven innovation: Extending the license to foster innovation. Management Decision, 48(1), 65-84.

Lave, J., \& Wenger, E. (1991). Situated learning: Legitimate peripheral participation. Cambridge: Cambridge University Press.

Malcolm, J., Hodkinson, P., \& Colley, H. (2003). The interrelationships between informal and formal learning. Journal of Workplace Learning, 15(7/8), 313-318.

Manuti, A., Pastore, S., Scardigno, A., Giancaspro, M., \& Morciano, D. (2015). Formal and informal learning in the workplace: A research review. International Journal of Training and Development, 19(1), 1-17.

Marsick, V., Watkins, K., Callahan, M., \& Volpe, M. (2008). Informal and incidental learning in the workplace. In M. Smith \& N. DeFrates-Densch (Eds.), Handbook of research on adult learning and development (pp. 570-599). New York: Routledge.

Matlay, H. (2004). Contemporary training initiative in Britain: A small business perspective. Journal of Small Business and Enterprise Development, 11(4), 504-513.

Møller, K. (2010). European innovation policy: A broad-based strategy? Transfer, 16(2), 155-169.

Pot, F. (2011). Workplace innovation for better jobs and performance. International Journal of Productivity and Performance Management, 30(4), 404-415.

Pot, F., Kraan, K., Oeij, P., Vergeer, R. \& Dhondt, S. (2012). Workplace innovation and its relations with organisational performance and employee commitment. LL LLinE, Lifelong Learning in Europe, 4. http:/www.elmmagazine.eu/articles/workplace-innovation-and-its-relations-with-organisationalperformance-and-employee-commitment/. Accessed 9 April 2017.

Price, O., Boud, D., \& Scheeres, H. (2012). Creating work: Employee-driven innovation through work practice reconstruction. In S. Høyrup, M. Bonnafous-Boucher, C. Hasse, M. Lotz, \& K. Møller (Eds.), Employee-driven innovation (pp. 77-91). Hampshire: Palgrave Macmillan.

Saunders, M., Gray, D., \& Goregaokar, H. (2013). SME innovation and learning: The role of networks and crisis events. European Journal of Training and Development, 38(1/2), 136-149.

Taisch, M. (2014). How to attract on a global scale young talents to manufacturing, key note speech at the 7 th Swedish Production Symposium, 16-18, Göteborg.

Teglborg, A. C., Redien-Collot, R., Bonnafous-Boucher, M., \& Viala, C. (2012). Employee-driven innovation: Operating in a chiaroscuro. In S. Høyrup, M. Bonnafous-Boucher, C. Hasse, M. Lotz, \& K. Møller (Eds.), Employee-driven innovation (pp. 34-56). Hampshire: Palgrave Macmillan.

Van Hootegem, G., Van Gyes, G. \& De Spiegelaere, S. (2012). Mainstreaming innovation in Europe Findings on employee innovation and workplace learning from Belgium. LLinE, Lifelong Learning in Europe, 4. http://www.elmmagazine.eu/articles/mainstreaming-innovation-in-europe-findings-onemployee-innovation-and-workplace-learning-from-belgium/. Accessed 9 April 2017.

Waite, E., Evans, K., \& Kersh, N. (2012). Employee-driven innovation amongst 'routine' employees in the UK: The role of organizational 'strategies' and individual 'tactics'. In S. Høyrup, M. Bonnafous-Boucher, C. Hasse, M. Lotz, \& K. Møller (Eds.), Employee-driven innovation (pp. 149-164). UK: Palgrave Macmillan.

Womack, J., \& Jones, D., 1996. Lean thinking: Banish waste and create wealth in your corporation. Simon and Schuster.

Womack, J., Jones, D., \& Roos, D. (1991). The machine that changed the world: The story of lean production. New York: Harper Perennial.

Agneta Halvarsson Lundkvist, a former evaluator of workplace development programmes. Her licentiate thesis, titled 'Steering through learning: a study of the dynamics of program development' (translated title) was completed in 2013. Her research interests are organizational change through workplace development programmes, and workplace innovation.

Maria Gustavsson, is a Professor in Education at the Department of Behavioural Sciences and Learning/ Education and Sociology, Linköping University. She is also a research leader at the Helix Competence Centre, at Linköping University. Gustavsson has a special research interest in workplace learning, vocational learning, organizational change and development, and workplace health promotion. Most recent research projects are Apprenticeship - conditions for learning vocational identities in industrial work, and Physicians' work conditions and health in emergency departments. 